\title{
In vitro androgenesis in pepper (Capsicum annuum L.) and the affecting factors on success: II. Carbohydrate source and antioxidants
}

\author{
Ergün Doğangüzel ${ }^{1} \oplus$, Fatma Nur Altındağ ${ }^{1} \oplus$, Merve Arefe Yiğit ${ }^{1}{ }^{\oplus}$, Şeküre Şebnem \\ Ellialtıoğlu² ${ }^{2}$, Nuray Çömlekçioğlu ${ }^{3, *}$
}

${ }^{1}$ R\&D Tissue Culture Laboratory, United Genetics Turkey, Mustafakemalpaşa, 16500 Bursa, Turkey.

${ }^{2}$ Department of Horticulture, Faculty of Agriculture, Ankara University, 06110 Ankara, Turkey.

${ }^{3}$ Department of Horticulture, Faculty of Agriculture, Osmangazi University, 26160 Eskişehir, Turkey.

\section{How to cite}

Doğangüzel, E., Altındağ, F. N., Yiğit, M. A., Ellialtıŏlu, Ş. Ş., \& Çömlekçioğlu, N. (2021). In vitro androgenesis in pepper (Capsicum annuum L.) and the affecting factors on success: II. Carbohydrate source and antioxidants. Biotech Studies. 30(2), 92-97 https://doi.org/10.38042/biotechstudies.1000341

\section{Article History \\ Received 23 May 2021 \\ Accepted 14 September 2021 \\ First Online 21 September 2021 \\ * Corresponding Author \\ Tel.: +90 2222393750 \\ E-mail: \\ nrycomlekcioglu@ogu.edu.tr}

\section{Keywords}

Capsicum annuum L.

Anther culture

Maltose

Ascorbic acid

Biotin

\begin{abstract}
Microspore cells develop into male gametophytes, which are released as pollen. Under certain stress conditions, the developmental pathway of microspores can be transformed into an embryo instead of pollen with haploid technology. In this experiment, 2 pepper breeding lines (G-1 and G-2) and 4 nutrient media formed with Murashige \& Skoog (1962-MS) $+30 \mathrm{~g} \mathrm{~L}^{-1}$ sucrose or maltose and with or without vitamins as antioxidants. $0.05 \mathrm{mg} \mathrm{L}^{-1}$ biotin (vitamin B7) and $0.5 \mathrm{mg} \mathrm{L}^{-1}$ ascorbic acid (vitamin C) were studied as antioxidants. The anthers were pretreated for 2 days at 35 으 in dark, then they were incubated in a climate chamber at $25{ }^{\circ} \mathrm{C}$ and $16 / 8$ hours photoperiodic conditions. The highest embryos rate, and development of embryos into the plantlet has been obtained from the medium containing maltose, and antioxidants. Although there was no significant differences between genotypes in medium- I (MS + sucrose), medium-II (MS + sucrose and antioxidants) and medium-III (MS + maltose) in terms of embryogenic response, a significant difference was determined between genotypes in medium-IV (MS + maltose and antioxidants). The number of embryos obtained from the G-1 in medium-IV has increased 2.5, 6.4, and 4.5 times, compared to the medium-I, medium-II, and medium-III respectively.
\end{abstract}

\section{Introduction}

Doubled haploidy (DH) system is a widely used tool in plant breeding, genetic research, and biotechnology today. The developmental pathway of a gamete cell can be changed and directed towards sporophytic development instead of mature pollen from microspore with double haploid technology. Accordingly, a gamete cell can form a haploid embryo alone, under certain stress conditions (Segui-Simarro \& Nuez, 2008; Shariatpanahi et al., 2006; Perez-Perez et al., 2019; Testillano, 2018, 2019; Cengiz \& Korkut, 2020). Stress pretreatments applied to anthers and microspores to inducing the sporophytic pathway are inhibit the gametophytic pathway and increase embryogenic potential (Sanchez et al., 2020). Microspores-induced embryo formation is called androgenesis.

In pepper anther culture, $35^{\circ} \mathrm{C}$ temperature pretreatment of anthers is the most commonly used stress condition. However, the levels of intracellular reactive oxygen species increase in microspores exposed to high temperature stress conditions and negatively affect the viability of microspores (Zur et al., 2009; Varnier et al., 2009; Gill \& Tuteja, 2010). 
Antioxidants reduce the oxidative stress in the plant and ensure the viability of microspores. Vitamin C (ascorbic acid) and vitamin B7 (biotin) are excellent free radical scavengers. They can provide tolerance to osmotic and oxidative stress in plants (Roje, 2007).

In Capsicum annuum L.; although different protocols have been employed to increase the productivity of anther culture during the 48 years since the first successful androgenic embryogenesis reported by Wang et al. (1973), George \& Narayanaswamy (1973), and Kuo et al. (1973), both embryo productivity and plantlet regeneration rate still have not reached the desired level.

Developing a successful protocol for producing $\mathrm{DH}$ plants in each plant species and variety is difficult and may take years. It is known that various factors such as donor plant genotype and growth conditions, culture methods, composition and hormonal composition of the nutrient medium, stress pretreatment that induces embryogenesis, and flower bud development period affect embryo productivity. Although protocols for the production of DHs exist for many species, conditions suitable for one species or one genotype may not work for another (Segui-Simarro \& Neuz, 2008; Irikova et al., 2011; Çömlekçioğlu \& Ellialtıoğlu, 2018). Therefore, these factors need to be studied in detail in order to precisely determine the combination that works for the donor plant genotype studied.

In order to encourage microspores to embryogenic development even in recalcitrant species, new targets need to be determined and new strategies should be devised. Therefore, in this study, the effects of two factors on the yield of haploid embryo, the carbon source (sucrose and maltose) used in the nutrient medium and the use of antioxidants (ascorbic acid and biotin), were investigated in two capia type pepper breeding lines.

\section{Materials and Methods}

This study was carried out in the greenhouse and tissue culture laboratories of United Genetics Vegetable Seeds Company (Mustafakemalpaşa, Bursa, Turkey). Two capia type pepper (Capsicum annuum L.) breeding lines of the company coded as G-1 and G-2 were used as the donor plant. Donor plants were grown in an unheated greenhouse. Donor plant seedlings were planted in the unheated greenhouse of United Genetics Turkey Vegetable Seeds Company in Mustafakemalpaşa/Bursa location on April 13, 2020. Flower bud harvesting for anther culture started on 20 May and continued until June 15. Table 1 shows the certain climatic variables of greenhouse for the experimental year for the months which experiments were conducted (from donor plants planting to the end of flower buds harvested). According to their morphological development, the buds in the developmental stage where the corolla, and calyx are the same height or the corolla height is slightly above the calyx height were collected and brought to the laboratory. Anthers at this developmental stage mostly have late uninucleate, and middle uninucleate microspores or are known to contain microspores in the young binucleate stage (Çömlekçioğlu \& Ellialtıoğlu, 2018).

Table 1. Temperature and relative humidity conditions of greenhouse during the experiments

\begin{tabular}{ccccc}
\hline $\begin{array}{c}\text { Year } \\
(2020)\end{array}$ & $\begin{array}{c}\text { Minimum } \\
\text { temperature } \\
\left({ }^{\circ} \mathrm{C}\right)\end{array}$ & $\begin{array}{c}\text { Average air } \\
\text { temperature } \\
\left({ }^{\circ} \mathrm{C}\right)\end{array}$ & $\begin{array}{c}\text { Max. air } \\
\text { temperature } \\
\left({ }^{\circ} \mathrm{C}\right)\end{array}$ & $\begin{array}{c}\text { Average } \\
\text { relative } \\
\text { humidity }\end{array}$ \\
\hline April & 13 & 24.0 & 35 & 48.6 \\
May & 16 & 26.5 & 37 & 47.9 \\
June & 17 & 27.0 & 38 & 54.2 \\
\hline
\end{tabular}

For surface sterilization, flower buds were first rinsed with water, then with $70 \%$ ethanol for $10-15$ seconds and kept in $10 \%$ commercial bleach (containing $5 \%$ sodium hypochlorite) and a drop of Tween-20 for 10 minutes. It was washed 3 times with sterile distilled water. The buds were carefully cut and isolated in a laminar flow cabinet on sterile paper.

In the experiment, four MS (Murashige \& Skoog, 1962) culture media, supplemented with sucrose or maltose, and with or without $5 \mathrm{mg} \mathrm{L}^{-1}$ ascorbic acid, 0.05 $\mathrm{mg} \mathrm{L}^{-1}$ biotin combination (as antioxidants) were used. In our previous study, $15 \mathrm{~g} \mathrm{~L}^{-1}, 30 \mathrm{~g} \mathrm{~L}^{-1}$, and $60 \mathrm{~g} \mathrm{~L}^{-1}$ maltose were tested and the best result was obtained from $30 \mathrm{~g} \mathrm{~L}^{-1}$. Therefore, $30 \mathrm{~g} \mathrm{~L}^{-1}$ maltose was studied in this study (Bat et al., 2020). All chemicals used in this experiment were Duchefa Biochemie brand. The culture media used are:

Medium-I (M-I); MS + $4 \mathrm{mg} \mathrm{L}^{-1}$ naphthalene acetic acid (NAA), $0.5 \mathrm{mg} \mathrm{L}^{-1}$ benzyl amino purine (BAP), $0.25 \%$ activated charcoal (AC) $15 \mathrm{mg} \mathrm{L}^{-1}$ silver nitrate $\left(\mathrm{AgNO}_{3}\right)$, $7 \mathrm{~g} \mathrm{~L}^{-1}$ agar, $30 \mathrm{~g} \mathrm{~L}^{-1}$ sucrose,

Medium-II (M-II); MS + $4 \mathrm{mg} \mathrm{L}^{-1} \mathrm{NAA}, 0.5 \mathrm{mg} \mathrm{L}^{-1}$ BAP, $0.25 \% \mathrm{AC}, 15 \mathrm{mg} \mathrm{L}^{-1} \mathrm{AgNO}_{3}, 30 \mathrm{~g} \mathrm{~L}^{-1}$ sucrose, $7 \mathrm{~g} \mathrm{~L}^{-1}$ agar, $0.5 \mathrm{mg} \mathrm{L}^{-1}$ ascorbic acid, $0.05 \mathrm{mg} \mathrm{L}^{-1}$ biotin,

Medium-III (M-I); MS + $4 \mathrm{mg} \mathrm{L}^{-1} \mathrm{NAA}, 0.5 \mathrm{mg} \mathrm{L}^{-1}$ BAP, $0.25 \%$ AC, $15 \mathrm{mg} \mathrm{L}^{-1} \mathrm{AgNO}_{3}, 7 \mathrm{~g} \mathrm{~L}^{-1}$ agar, $30 \mathrm{~g} \mathrm{~L}^{-1}$ maltose,

Medium-IV (M-IV); MS + $4 \mathrm{mg} \mathrm{L}^{-1} \mathrm{NAA}, 0.5 \mathrm{mg} \mathrm{L}^{-1}$ BAP, $0.25 \% \mathrm{AC}, 15 \mathrm{mg} \mathrm{L}^{-1} \mathrm{AgNO}_{3}, 7 \mathrm{~g} \mathrm{~L}^{-1}$ agar, $30 \mathrm{~g} \mathrm{~L}^{-1}$ maltose, $0.5 \mathrm{mg} \mathrm{L}^{-1}$ ascorbic acid, $0.05 \mathrm{mg} \mathrm{L}^{-1}$ biotin.

Anthers planted on nutrient media were exposed to heat pre-treatment at $35^{\circ} \mathrm{C}$ under continuous darkness for the first 2 days. It was then incubated at $25^{\circ} \mathrm{C}$ under photoperiod conditions for $16 / 8$ hours.

\section{Statistical Analysis}

The experiment was carried out in a randomized block design with 3 replications. At each replication, 100 anthers were cultured in 10 Petri dishes containing 10 anthers each. The data were subjected to analysis of variance (ANOVA) using Tarist (Açlkgöz et al., 2004). Mean separation was performed by Fisher's Least Significance Difference (LSD) $(p<0.01)$. 
Table 2. Summary of ANOVA for total embryos obtained, embryo rate and regenerated plantlets

\begin{tabular}{|c|c|c|c|c|c|c|c|}
\hline \multirow{2}{*}{$\begin{array}{l}\text { Source of } \\
\text { variation }\end{array}$} & \multirow[t]{2}{*}{ DF } & \multicolumn{2}{|l|}{ Total embryos } & \multicolumn{2}{|c|}{ Embryo rate (embryo per 100 anther) } & \multicolumn{2}{|c|}{ Number of regenerated plantlets } \\
\hline & & Mean square & F-value & Mean square & F-value & Mean square & F-value \\
\hline Genotype (G) & 1 & 70.04 & $175.63^{* *}$ & 81.29 & $154.67^{* *}$ & 4.10 & $21.18 * *$ \\
\hline Media (M) & 3 & 160.82 & $403.25 * *$ & 207.04 & $393.93 * *$ & 30.23 & $156.31 * *$ \\
\hline GXM & 3 & 43.60 & $109.32 * *$ & 30.01 & $57.09 * *$ & 19.63 & $101.52 * *$ \\
\hline Error & 14 & 0.39 & & 0.53 & & 0.19 & \\
\hline Total & 23 & 30.03 & & 34.86 & & 7.45 & \\
\hline
\end{tabular}

*Significant at alfa level 5\%; ** Significant at alfa level 1\%; DF= Degrees of freedom

\section{Results and Discussion}

This study was conducted to examine the androgenesis response of pepper to the carbohydrate source (sucrose or maltose) and 'biotin + ascorbic acid' supplementation as antioxidants in the nutrient medium. In this study, 4 different nutrient media were tested. Variance analysis results are presented in Table 2. Approximately 2 months (58 days) after the anthers were cultured, the first embryos were seen and embryo formation continued for almost 5 months.

The number of embryos obtained showed significant differences according to genotype, nutrient medium, and 'genotype $\times$ medium' interaction. Both genotypes produced a higher number of embryos in $\mathrm{M}$ I and M-IV compared to the M-II, and M-III. While G-I produced the highest number of embryos in $M-I V$, gave a similar number of embryos in M-II and M-III. G-2 produced a higher number of embryos in $\mathrm{M}-\mathrm{I}$ and $\mathrm{M}-\mathrm{IV}$ compared to the M-II, and M-III. In the M-IV, the difference between the 2 genotypes was found to be very significant (Table 3 ). In this experiment, it was determined that the genotype effect was more important than the nutrient medium.

Genotype $\times$ medium interaction was found important in terms of androgenesis rate (embryo obtained per 100 anthers). The highest rate of the embryo was obtained from G-1 in M-IV. Both genotypes had the lowest values in M-II containing sucrose, and ascorbic acid, and biotin. It has been determined that adjusting the most suitable nutrient medium according to the genotype is important in androgenesis.

Figure 1 shows a few microspore-derived embryos and fully developed green plantlets obtained from this experiment. While some of the embryos obtained from the culture develop into a complete plantlet, some embryos cannot form green plants. Accordingly, it was determined that the number of plantlets developed from the obtained embryos differed significantly in terms of genotypes, media, and their interactions. The lowest plantlet growth was determined in the M-II and the highest in $\mathrm{M}-\mathrm{IV}$, parallel to the number of the embryos obtained (Table 3 ).

The results showed that the interaction of ascorbic acid, and biotin combination with different carbohydrate sources is important. While determining the negative effects of ascorbic acid and biotin combination on embryogenesis in sucrose contained medium, it has been observed that ascorbic acid and biotin combination has a significant positive effect in maltose content medium. The type of sugar used in the nutrient medium had a significant effect on androgenesis, and maltose had a positive effect on inducing haploid embryo formation. The combination of $30 \mathrm{~g} \mathrm{~L}^{-1}$ maltose, $0.5 \mathrm{mg} \mathrm{L}^{-1}$ ascorbic acid, and $0.05 \mathrm{mg} \mathrm{L}^{-}$ ${ }^{1}$ biotin was the best culture medium for induction of high-frequency embryogenesis $(26.1 \%$ for $\mathrm{G}-1$ and $16.4 \%$ for $\mathrm{G}-2$ ). Both genotypes gave similar results in terms of embryogenic response in $\mathrm{M}-\mathrm{I}, \mathrm{M}-\mathrm{II}$, and $\mathrm{M}-\mathrm{III}$, whereas a significant difference was detected between genotypes in medium-IV. The number of embryos obtained from G-I increased 2.5, 6.4, and 4.5 times, compared to the $\mathrm{M}-\mathrm{I}, \mathrm{M}-\mathrm{II}$, and $\mathrm{M}$-III respectively. The effect of the culture medium on the success of anther culture in interaction with the genotype was clearly demonstrated in the study.

Cheng et al. (2020) reported that stress pretreatments to anthers are necessary to induce embryo development from microspores, and heat stress applications in peppers are indispensable since plant regeneration cannot be achieved without heat pretreatment. Stress applications used to reprogram microspores for embryogenesis often cause cell death.

Table 3. Total number of embryos, embryo ratio and number of plantlets obtained according to nutrient media and genotypes

\begin{tabular}{|c|c|c|c|c|c|c|c|c|c|}
\hline \multirow[t]{2}{*}{ Medium } & \multicolumn{3}{|c|}{ Number of embryos } & \multicolumn{3}{|c|}{$\begin{array}{c}\text { Embryo rate } \\
\text { (Embryo no/100 anthers)* }^{*}\end{array}$} & \multicolumn{3}{|c|}{ Number of the plantlets } \\
\hline & G-1 & G-2 & Mean & G-1 & G-2 & Mean & G-1 & G-2 & Mean \\
\hline$M-I$ & $7.7 \mathrm{~b}$ & 8. $3 a$ & $8.0 \mathrm{~b}$ & $16.1 \mathrm{~b}$ & $16.8 \mathrm{a}$ & $16.4 \mathrm{~b}$ & $3.0 \mathrm{~b}$ & $4.3 \mathrm{a}$ & $3.7 \mathrm{~b}$ \\
\hline$M-I I$ & $3.0 \mathrm{c}$ & $1.0 \mathrm{c}$ & $2.0 \mathrm{~d}$ & $9.9 \mathrm{~d}$ & $5.7 \mathrm{~d}$ & $7.9 \mathrm{~d}$ & $1.0 \mathrm{c}$ & $1.0 \mathrm{c}$ & $1.0 \mathrm{c}$ \\
\hline$M-I I I$ & $4.3 c$ & $3.3 \mathrm{~b}$ & $3.8 \mathrm{c}$ & $12.0 \mathrm{c}$ & $10.5 \mathrm{c}$ & $11.2 \mathrm{c}$ & $1.3 \mathrm{c}$ & $1.7 \mathrm{c}$ & $1.5 \mathrm{c}$ \\
\hline$M-I V$ & $19.3 \mathrm{a}$ & $8.0 \mathrm{a}$ & $13.7 \mathrm{a}$ & $26.1 \mathrm{a}$ & $16.4 \mathrm{a}$ & $21.3 \mathrm{a}$ & $9.3 \mathrm{a}$ & $3.0 \mathrm{~b}$ & $6.2 \mathrm{a}$ \\
\hline Mean & $8.5 \mathrm{a}$ & $5.2 \mathrm{~b}$ & & 16.0 a & $12.4 \mathrm{~b}$ & & $3.7 \mathrm{a}$ & $2.8 \mathrm{~b}$ & \\
\hline
\end{tabular}




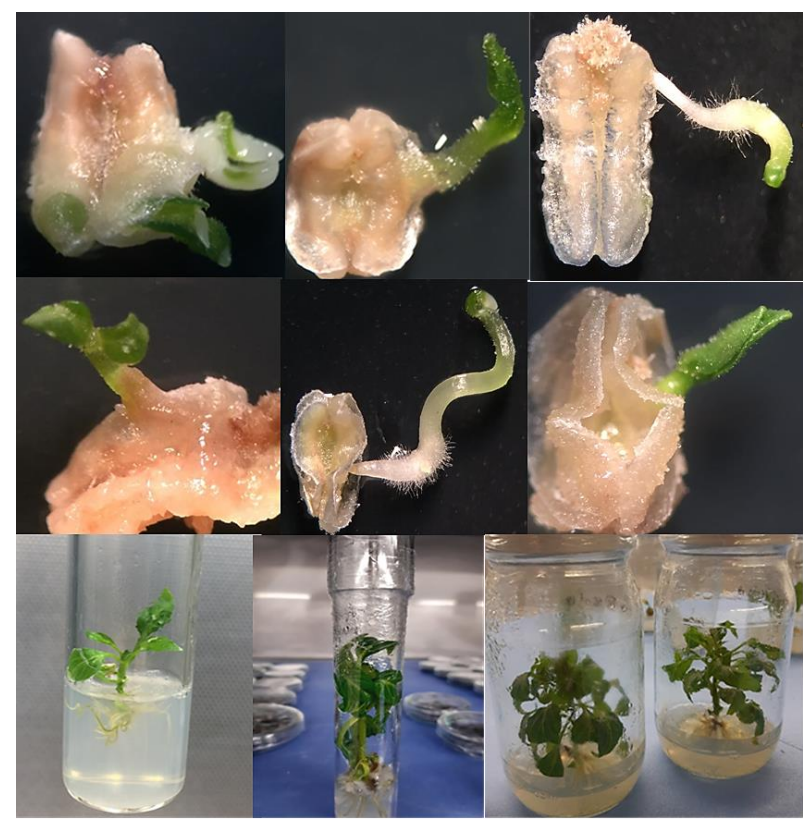

Figure 1. Some of microspore-derived embryos and plantlets obtained from the cultures.

It is the main factor that greatly reduces the efficiency of the method in transition to embryogenesis (Testillano, 2018; Rodriguez-Serrano et al., 2012). It limits the use of these methods in many plants because of low totipotens, and embryogenesis, thus appropriate stress conditions must be applied. Stress applied for the induction of embryogenesis causes an increase in reactive oxygen species (ROS) in microspore cells, and death (Zur et al., 2009; Rodriguez-Serrano et al., 2012). In order to prevent oxidative damage in the cell and to control cell death, ROS cleaning applications are of great importance. ROS scavenging roles of vitamins in plant cells have been reported previously (Becker et al., 2014; Zur et al., 2009; El-Sharabasy, 2019).

It has been reported that the vitamins in the culture medium increase the microspore viability and thus the embryogenesis response improves (Al-Khayri, 2001; Roje, 2007; Habibi et al., 2009; Hoseini et al., 2013; Zeng et al., 2015; Ozsan \& Onus, 2017). It has been reported that it is important to increase the tolerance of microspore cells against oxidative stress caused by the stress pretreatments applied to anthers. Due to antioxidant properties of certain vitamins in the nutrient medium is a factor that increases the androgenic embryo yield (Demirkaya \& Comlekcioglu, 2021). Navarro-Alvarez et al. (2006) reported that carbohydrates are critical components in anther culture medium for successful somatic embryo initiation, and plant regeneration. He reported that galactose and mannose did not support embryo formation, while glucose gave more positive results than sucrose and fructose. However, the highest rate of embryos in three wheat genotypes was obtained from the medium containing maltose.

In pepper anther culture, sucrose is the most commonly used carbohydrate source in culture media
(Taskın et al., 2011; Çömlekçioğlu \& Ellialtıoğlu, 2018). However, there are studies reporting that maltose as a carbohydrate source is more effective for androgenesis compared to sucrose. Last et al. (1990) reported that when maltose is used instead of sucrose in wheat anther culture, a three to four-fold increase in embryo yield was observed although it varied according to genotypes. Trejo-Tapia et al. (2002) found that maltose is the most effective carbohydrate in callus induction. Bat et al. (2020) compared $15 \mathrm{~g} \mathrm{~L}^{-1}, 30 \mathrm{~g} \mathrm{~L}^{-1}$, and $60 \mathrm{~g} \mathrm{~L}^{-1}$ maltose doses with $30 \mathrm{~g} \mathrm{~L}^{-1}$ sucrose in a study with 3 pepper genotypes. While emphasizing the importance of the genotype effect in the androgenetic response, the study results also showed that a significantly higher embryo formation was achieved in a medium containing $15 \mathrm{~g} \mathrm{~L}^{-1}$ and $30 \mathrm{~g} \mathrm{~L}^{-1}$ maltose compared to a medium containing $30 \mathrm{~g} \mathrm{~L}^{-1}$ sucrose.

In a small number of trials using maltose (Irikova et al., 2011), maltose was generally used alone and different carbohydrate sources were not compared in the studied genotypes. Geboloğlu et al. (2017) reported that the use of honey instead of sucrose in eggplant anther culture has a positive effect on obtaining embryos, with the highest number of embryo formation being $18.35 \%$ and $20.95 \%$ from honey and sucrose treatment, respectively.

Although pepper is one of the most intensively studied plants on androgenesis, DH production in this species is still not at the desired level. The relationship between androgenetic response and nutrient medium composition in peppers has been widely accepted. However, although it is known that carbohydrate sources and doses in the nutrient medium affect embryogenesis, studies have focused on growth regulators and the relationship of their doses with the embryogenic potential of microspores rather than determining the most appropriate carbohydrate source, and doses.

It has been determined that the applications are very promising in terms of increasing the yield of haploid embryos with the anther culture method, as well as on the rate of obtaining plantlets from the formed embryos. It is thought that different carbohydrate sources and doses should be studied in also other recalcitrant species to increase the efficiency of haploid embryogenesis, and plantlet regeneration. While emphasizing the importance of the genotype effect once again in the study, it was determined that different factors should be studied in detail in pepper anther culture. Genotype effect in anther culture response is an important factor limiting the application of this technology in plant breeding. This requires the experimental development of culture media, and protocols for different genotypes. Culture protocols that can be successfully applied in different genotypes need to be developed, and optimized. 


\section{Acknowledgements}

We acknowledge the Scientific and Technological Research Council of Turkey (TÜBITAK) for supporting the project of 3170610-TÜBITAK-TEYDEB- AGY300-03 and United Genetics Turkey Seed Company about their R\&D tissue culture laboratory.

\section{Author Contributions}

Conceptualization, writing-review and editing: NC, SSE; Methodology: FNA, MAY, ED; Data curation, Formal analysis: ED.

\section{References}

Açıkgöz, N., Illker, E., \& Gökçöl, A. (2004). Biyolojik araştırmaların bilgisayarda değerlendirilmeleri, Ege Üniversitesi Tohum Teknolojisi Uygulama ve Araştırma Merkezi Yayınları No: 2, Ege Üniversitesi Ziraat Fakültesi ofset atölyesi (in Turkish).

Al-Khayri J. M. (2001). Optimization of biotin and thiamine requirements for somatic embryogenesis of date palm (Phoenix dactylifera L.). In vitro Cellular \&Developmental Biology Plant, 37(4), 453-456. http://doi.org/10.1079/IVP2001200

Bat, H., Shidfar, M., Çömlekçioğlu, N., \& Ellialtıoğlu Ş. Ş. (2020). In vitro androgenesis in pepper and the affecting factors on success: I. Carbon source and concentrations. Biotech Studies, 29(2),

62-68. http://doi.org/10.38042/biost.2020.29.02.02

Becker M. G., Chan A., Mao X., Girard I. J., Lee S., Elhiti M., Stasolla, C., \& Belmonte, M. F. (2014). Vitamin C deficiency improves somatic embryo development through distinct gene regulatory networks in Arabidopsis. J Exp. Bot., 65, 5903-5918. https://doi.org/10.1093/jxb/eru330

Cengiz, R. \& Korkut, Z. K. (2020). Development of doubled haploid maize lines by using in vivo haploid technique. Biotech Studies, 29(1), 1-7. http://doi.org/10.38042/biost.2020.29.01.01

Cheng, Y., Jiao, Y., Miao, R., Tian, R., Liang Y., \& Qiao, N. (2020). Exploring differentially expressed genes of microspore embryogenesis under heat stress in sweet pepper. African Journal of Biotechnology, 19(9), 661-674. https://doi.org/10.5897/AJB2020.17194

Çömlekçioğlu N., \& Ellialtıoğlu, Ş. Ş. (2018). Review on the research carried out on in vitro androgenesis of peppers (Capsicum annuum L.) in Turkey. Research Journal of Biotechnology, 13(6), 75-84.

Demirkaya, B. \& Comlekcioglu, N. (2021). Effects of biotin and ascorbic acid applications on haploid embryo induction in semisolid and double layer nutrient media in pepper (Capsicum annuum L.) anther culture. Int. J. Agric. Environ. Food Sci., 5(2), 191-196. https://doi.org/10.31015/jaefs.2021.2.8

El-Sharabasy, S. F., Bosila, H. A., Abdel-Aal, W. B., Mansour, B. M., \& Bana A. A. (2019). Effect of vitamins (pyridoxine and nicotinic acid), Thiamine- $\mathrm{HCl}$ and Myo-inositol at different concentrations on free amino acids and indoles content of embryogenic callus of in vitro date palm (Sakkoty and Bartamuda cultivars) materials. Research
Proceedings,

11

https://doi.org/10.21741/9781644900178-20

Geboloğlu, N., Doksöz Boncukçu, S., Durna, P. \& Bayram, M. (2017). Patlıcanda Şeker, Bal ve Büyüme Düzenleyicilerin Anter Kültüründe Embriyoid Oluşumuna Etkisi. Akademik Ziraat Dergisi 6, 275-280.

George, L., \& Narayanaswamy, S. (1973). Haploid Capsicum through experimental androgenesis. Protoplasma, 78 (4), 467-470. https://doi.org/10.1007/BF01275781

Gill, S. S., \& Tuteja, N. (2010). Reactive oxygen species and antioxidant machinery in abiotic stress tolerance in crop plants. Plant Physiology and Biochemistry, 48(12): 909930. https://doi.org/10.1016/i.plaphy.2010.08.016

Habibi, N., Suthar, P. K., \& Purohit, S. D. (2009). Role of PGRs and inhibitors in induction and control of somatic embryogenesis in Themeda quadrivalvis. Indian Journal of Experimental Biology, 47 (3), 198-203. PMID: 19405386

Hoseini, M., Ghadimzadeh, M., Ahmadi, B. A. J., \& Silva, T. (2014). Effects of ascorbic acid, -tocopherol, and glutathione on microspore embryogenesis in Brassica napus L. In Vitro Cellular \& Developmental Biology-Plant, 50(1), 26-35. https://doi.org/10.1007/s11627-0139579-8

Irıkova, T., Grozeva, S., Popov, P., Rodeva, V., \& Todorovska, E. (2011). In vitro response of pepper anther culture (Capsicum annuum L.) depending on genotype, nutrient medium and duration of cultivation. Biotechnology and Biotechnological Equipment, 25(4), 2604-2609. https://doi.org/10.5504/BBEQ.2011.0090

Kuo, J. S., Wang, Z. Z., Chien, N. F., Ku, S. J., Kung, M. L., \& Hsu, H. C. (1973). Investigation on the anther culture in vitro of Nicotiana tabacum L. and Capsicum annuum L. Acta Botanica Sinica, 15(1), 43-47.

Last, D. I., \& Brettell, R. I. S. (1990). Embryo yield in wheat anther culture is influenced by the choice of sugar in the culture medium. Plant Cell Reports, 9, 14-16. https://doi.org/10.1007/BF00232126

Murashige, T., \& Skoog, F. (1962). A revised medium for rapid growth and bioassays with tobacco tissue cultures. Physiol. Plant., 15, 473-497. https://doi.org/10.1111/i.1399-3054.1962.tb08052.x

Navarro-Alvarez, W., Baenziger, P. S., Eskridge K. M., Shelton, D. R., Gustafson, V. D., \& Hugo, M. (2006). Effect of sugars in wheat anther culture media. Plant Breeding, 112(1), 53-62. https://doi.org/10.1111/j.14390523.1994.tb01276.x

Ozsan, T., \& Onus, A. N. (2017). In vitro pepper (Capsicum annuum L.) anther culture: Can be affected via vitamins B?. Biotechnology Journal International, 20(1), 1-13. https://doi.org/10.9734/BJI/2017/37102

Perez-Perez, Y., El-Tantawy, A. A., Solis, M. T., Risueno, M. C., \& Testillano, P. S. (2019). Stress-induced microspore embryogenesis requires endogenous auxin synthesis and polar transport in barley. Front. Plant Sci., 10:1200. https://doi.org/10.3389/fpls.2019.01200

Rodriguez-Serrano, M., Barany, I., Prem, D., Coronado, M. J., Risueno, M. C., \& Testilano, P. S. (2012). NO, ROS, and cell death associated with caspase-like activity increase in stress induced microspore embryogenesis of barley. $J$. of Experimental Botany, 63(5): 2007-24. https://doi.org/10.1093/ixb/err400

Roje, S. (2007). Vitamin B biosynthesis in plants. Phytochemistry, 68, 1904-1921. https://doi.org/10.1016/j.phytocochem.2007.03.038 
Sanchez, M. A., Coronado, Y. M., \& Coronado, A. C. M. (2020). Androgenic studies in the production of haploids and doubled haploids in Capsicum spp. Revista Facultad Nacional de Agronomia Medellin, 73, 9047-9056. https://doi.org/10.15446/rfnam.v73n1.76044

Segui-Simarro, J. M., \& Nuez, F. (2008). How microspores transform into haploid embryos: changes associated with embryogenesis induction and microspore derived embryogenesis. Physiologia Plantarum, 134(1), 1-12. https://doi.org/10.1111/j.1399-3054.2008.01113.x.

Shariatpanahi, M. E., Bal, U., Heberle-Bors E., \& Touraev, A. (2006). Stresses applied for the re-programming of plant microspores towards in vitro embryogenesis. Physiologia Plantarum, 127(4), 519-534. https://doi.org/10.1111/i.1399-3054.2006.00675.x

Testillano, P. S. (2018). Stress-induced microspore embryogenesis in crop plants: Cell totipotency acquisition and embryo development. In: Cánovas F., Lüttge U., Leuschner C., Risueño MC. (eds) Progress in Botany Vol. 81. Progress in Botany, vol 81. Springer, Cham. https://doi.org/10.1007/124 201824

Taskin, H., Buyukalaca, S., Keles, D., \& Ekbic, E. (2011). Induction of microspore-derived embryos by anther culture in selected pepper genotypes. African Journal of Biotechnology. https://doi.org/10.5897/AJB11.2023

Testillano, P. S. (2019). Microspore embryogenesis: targeting the determinant factors of stress-induced cell reprogramming for crop improvement. Journal of Experimental Botany, 70(11), 2965-2978. https://doi.org/10.1093/jxb/ery464.
Trejo-Tapia, G., Amaya, U. M., Morales, G. S., Sanchez, A. D. J., Bonfil, B. M., Monroy, M. R., \& Jimenez-Aparicio, A. (2002). The effects of cold-pretreatment, auxins and carbon source on anther culture of rice. Plant Cell, Tissue and Organ Culture, 71, 41-46. https://doi.org/10.1023/A:1016558025840

Wang, Y. Y., Sun, C. S., Wang, C. C., \& Chien, N. F. (1973). The induction of the pollen plantlets of triticale and Capsicum annuum L. from anther culture. Science Sinica, 16, 147-151.

Varnier A. L., Jacquard C., \& Clement C. (2009) Programmed cell death and microspore embryogenesis. In: Touraev A., Forster B.P., Jain S.M. (eds) Advances in Haploid Production in higher plants. Springer, Dordrecht. 147154. https://doi.org/10.1007/978-1-4020-8854- 411

Zeng, A., Yan, J., Song, L., Gao, B., \& Li, J. (2015). Effects of ascorbic acid and embryogenic microspore selection on embryogenesis in white cabbage (Brassica oleracea $\mathrm{L}$. var. capitata). The Journal of Horticultural Science and Biotechnology, 90(6), 607-612. https://doi.org/10.1080/14620316.2015.11668722

Zur, I., Dubas, E., Golemiec, E., Szechyńska-Hebda, M., Golebiowska, G., \& Wedzony, M. (2009). Stress-related variation in anti-oxidative enzymes activity and cell metabolism efficiency associated with embryogenesis induction in isolated microspore culture of Triticale ( $x$ Triticosecale Wittm.). Plant Cell Rep., 28, 1279-1287. https://doi.org/10.1007/s00299-009-0730-2 